\title{
Frequency Distribution of Steady-state Oxygen Partial Pressures in Modified-atmosphere Packages of Cut Broccoli
}

\author{
Panchanadham C. Talasila ${ }^{1}$, Arthur C. Cameron ${ }^{2}$, and Dennis W. Joles ${ }^{3}$ \\ Horticulture Department, Michigan State University, East Lansing, MI 48824-1325 \\ Additional index words. Brassica oleracea, packaging, respiration rate, film permeability, vegetables, modeling
}

\begin{abstract}
In one set of modified-atmosphere (MA) packages of cut broccoli (Brassica oleracea L., Italica Group), $\mathrm{O}_{2}$ partial pressures ranged from 1.2 to $3.6 \mathrm{kPa}$ at $0 \mathrm{C}$ [88 packages, 0.00268 -cm-thick low-density polyethylene (LDPE) film, 600$\mathrm{cm}^{2}$ film area, $40 \pm 0.5 \mathrm{~g}$ cut broccoli], and in another set (94 packages, same film and area as before, $25 \pm 0.5 \mathrm{~g}$ cut broccoli) they ranged from 5.0 to $9.2 \mathrm{kPa}$. For characterizing $\mathrm{O}_{2}$ uptake as a function of $\mathrm{O}_{2}$ partial pressure and determining anaerobic fermentation induction point at $\mathrm{OC}$, a range of steady-state package $\mathrm{O}_{2}$ partial pressures was generated by placing different amounts of cut broccoli $(10$ to $160 \mathrm{~g})$ in LDPE packages. Oxygen uptake was modeled using a Michaelis-Menten-type equation. The maximum rate of product $\mathrm{O}_{2}$ uptake when $\mathrm{O}_{2}$ partial pressure was nonlimiting and the package $\mathrm{O}_{2}$ partial pressure corresponding to half-maximum $\mathrm{O}_{2}$ uptake were estimated as $147 \pm 3 \mathrm{nmol} \cdot \mathrm{kg}^{-1} \cdot \mathrm{s}^{-1}$ and $0.26 \pm 0.025 \mathrm{kPa}$, respectively. Respiratory quotient and head space ethanol increased sharply below package $\mathrm{O}_{2}$ partial pressures of $0.15 \mathrm{kPa}$, indicating stimulation of fermentation within the packages. The frequency distributions of $\mathrm{CO}_{2}$ production rates were measured for 80 samples of $100 \mathrm{~g}$ each of cut broccoli at two $\mathrm{O}_{2}$ partial pressures $(21.0 \mathrm{kPa}$ and 1.3 $\mathrm{kPa}$ ) using a flow-through method. The average coefficient of variation of the $\mathrm{CO}_{2}$ production rate was $\approx 5 \%$. Frequency distributions of $\mathrm{O}_{2}$ partial pressures were modeled as a function of product-to-product variation in $\mathrm{O}_{2}$ uptake and package-to-package variation in film permeability using the estimated $\mathrm{O}_{2}$ uptake characteristics and coefficient of variation. The model was used to predict the target $\mathrm{O}_{2}$ partial pressures for the design of cut broccoli MA packages. It was predicted that the packages for cut broccoli at $0 \mathrm{C}$ should be designed for a target $\mathrm{O}_{2}$ partial pressure of $2.54 \mathrm{kPa}$ to have actual package $\mathrm{O}_{2}$ partial pressures $\geq 1.0 \mathrm{kPa}$ at $0.0001 \%$ probability level. Film specifications for MA packaging of cut broccoli at $0 \mathrm{C}$ were calculated based on the predicted target $\mathrm{O}_{2}$ partial pressures.
\end{abstract}

The basic purpose of modified-atmosphere (MA) packaging is to generate potentially useful levels of gases (e.g., $\mathrm{O}_{2}, \mathrm{CO}_{2}, \mathrm{H}_{2} \mathrm{O}$ ) for extending the storage life of fresh and minimally processed fruit and vegetables. A given atmosphere for a product is created in MA packages by matching film permeability with product respiration rate (Beaudry et al., 1992; Cameron et al., 1989; Kader et al., 1989). However, steady-state partial pressures of a gas such as $\mathrm{O}_{2}$ will vary from target $\mathrm{O}_{2}$ partial pressures due to a number of factors including variation in product $\mathrm{O}_{2}$ uptake or film permeability to $\mathrm{O}_{2}$. Successful MA packages must be designed so that these variations do not cause undesirable changes to product quality. Such changes could include external and internal discoloration, off-flavor development, and the growth of microorganisms that cause food poisoning.

It has been reported that $1 \%$ to $3 \% \mathrm{O}_{2}$ and/or $5 \%$ to $10 \% \mathrm{CO}_{2}$ is beneficial for broccoli storage (Lipton and Harris, 1974; Makhlouf et al., 1989; Refrigeration Research Foundation, 1988; Smith, 1940). Low $\mathrm{O}_{2}$ retards curd yellowing (Lipton and Harris, 1974), while high $\mathrm{CO}_{2}$ has reduced yellowing (Kasmire et al., 1974; Lipton and Harris, 1974; Makhlouf et al., 1989) and decay (Lipton and Harris, 1974; Makhlouf et al., 1989; Smith, 1940). The effect of MAs was more prominent when storage temperature was $>5 \mathrm{C}$ (Lipton and Harris, 1974).

Received for publication 27 Sept. 1993. Accepted for publication 10 Mar. 1994. This research was supported by BARD project no. US-1913-90R. Mention of a trademark, proprietary product, or vendor does not constitute a guarantee or warranty of the product by Michigan State Univ. and does not imply its approval to the exclusion of other products or vendors that also may be suitable. The cost of publishing this paper was defrayed in part by the payment of page charges. Under postal regulations, this paper therefore must be hereby marked advertisement solely to indicate this fact.

${ }^{1}$ Postdoctoral research associate.

${ }^{2}$ Associate professor.

${ }^{3}$ Graduate assistant.
Lipton and Harris (1974) reported that $\mathrm{O}_{2}$ concentrations $<0.1 \%$ caused severe visible low- $\mathrm{O}_{2}$ injury and concentrations $<0.25 \%$ induced off-flavors at temperatures $>2.5 \mathrm{C}$. Kasmire et al. (1974) noticed slight off-flavors at $\mathrm{O}_{2}$ concentrations as high as $1 \%$ after holding for 9 days at 2.5C. Carbon dioxide concentrations $>10 \%$ can also cause off-flavors and physiological injury (Kasmire et al., 1974; Lipton and Harris, 1974; Makhlouf et al., 1989; Smith, 1940). A combination of $1 \% \mathrm{O}_{2}$ with $20 \% \mathrm{CO}_{2}$ resulted in off-flavors comparable to $0.5 \% \mathrm{O}_{2}$ without any added $\mathrm{CO}_{2}$ (Kasmire et al., 1974).

Random variation in product $\mathrm{O}_{2}$ uptake and/or film permeability to $\mathrm{O}_{2}$ will generate a frequency distribution of package $\mathrm{O}_{2}$ partial pressures. This will create a potential risk for some packages containing cut broccoli to develop injurious $\mathrm{O}_{2}$ partial pressures, even if the packages are designed for a target $\mathrm{O}_{2}$ partial pressure in the optimal range. This risk cannot be avoided, even with perfect temperature control. To our knowledge, there has not been any reported work on the frequency distribution of $\mathrm{O}_{2}$ partial pressures among individual MA packages of cut broccoli or any crop.

A general model that predicts the frequency distribution of package $\mathrm{O}_{2}$ partial pressures for a given frequency distribution in product $\mathrm{O}_{2}$ uptake and film permeability to $\mathrm{O}_{2}$ has been developed (Talasila and Cameron, 1994). This model provides an approach for designing MA packages so that the package $\mathrm{O}_{2}$ partial pressures at steady-state will be less than or equal to a certain limit only with a given probability. Information on the $\mathrm{K}_{1 / 2}$ value (a constant in the place of $\mathrm{K}_{\mathrm{m}}$ in a Michaelis-Menten type equation of $\mathrm{O}_{2}$ uptake as a function of $\mathrm{O}_{2}$ partial pressure) (Cameron et al., 1994; Lee et al., 1991) and a minimum $\mathrm{O}_{2}$ limit for safe product storage are required for using this model.

The primary objectives of this work were to measure and model the frequency distributions of $\mathrm{O}_{2}$ partial pressures among cutbroccoli packages at $0 \mathrm{C}$ as they relate to an MA package design that would be safe from developing $\mathrm{O}_{2}$ partial pressures below a 
certain limit. For this purpose, we characterized 1) $\mathrm{O}_{2}$ uptake as a function of $\mathrm{O}_{2}$ partial pressure, 2) the anaerobic fermentation induction point, and 3 ) the frequency distribution of $\mathrm{CO}_{2}$ production rates of cut broccoli at $0 \mathrm{C}$.

\section{Theoretical Background}

Following is a brief presentation of a model that predicts the frequency distribution of package $\mathrm{O}_{2}$ partial pressures among individual packages (Talasila and Cameron, 1994).

In developing the model, it was assumed that the package $\mathrm{O}_{2}$ partial pressure $\left(\left[\mathrm{O}_{2}\right]_{\mathrm{pkg}}\right.$; see Appendix) would be equal to median package $\mathrm{O}_{2}$ partial pressure $\left(\left[\mathrm{O}_{2}\right]_{\text {med }}\right)$ when the $\mathrm{O}_{2}$ uptake of the product in a package was equal to the mean $\mathrm{O}_{2}$ uptake $\left(\overline{\mathrm{R}}_{\mathrm{O}_{2}}\right)$ and film permeability to $\mathrm{O}_{2}$ was equal to the mean film permeability $\left(\overline{\mathrm{P}}_{\mathrm{O}_{2}}\right)$. $\left[\mathrm{O}_{2}\right]_{\text {med }}$ will not necessarily be equal to the arithmetic mean, as the frequency distribution may not always be normal. $\left[\mathrm{O}_{2}\right]_{\mathrm{med}}$ was taken as the $\mathrm{O}_{2}$ partial pressure for which $50 \%$ of the observations, when arranged in ascending or descending order of magnitude, was lying on each side. Product $\mathrm{O}_{2}$ uptake was assumed to follow a Michaelis-Menten-type equation:

$$
\overline{\mathrm{R}}_{\mathrm{O}_{2}}=\frac{\mathrm{R}_{\mathrm{O}_{2}}^{\max } \cdot\left[\mathrm{O}_{2}\right]_{\mathrm{med}}}{\mathrm{K}_{1 / 2}+\left[\mathrm{O}_{2}\right]_{\mathrm{med}}}
$$

where $\mathrm{R}_{\mathrm{O}_{2}}$ max and $\mathrm{K}_{1 / 2}$ are parameters in a Michaelis- Menten-type equation of product $\mathrm{O}_{2}$ uptake as a function of package $\mathrm{O}_{2}$ partial pressure.

If the $\mathrm{O}_{2}$ uptake of the product in a package $\left(\mathrm{R}_{\mathrm{O}_{2}}\right)$ and the permeability to $\mathrm{O}_{2}\left(\mathrm{P}_{\mathrm{O}_{2}}\right)$ of the film used in making the package are different from the mean values of their respective populations $\left(\overline{\mathrm{R}}_{\mathrm{O}_{2}}\right.$ and $\overline{\mathrm{P}}_{\mathrm{O}_{2}}$ ), the steady-state $\mathrm{O}_{2}$ partial pressure in that package $\left(\left[\mathrm{O}_{2}\right]_{\mathrm{pkg}}\right)$ will be different from the median $\mathrm{O}_{2}$ partial pressure $\left(\left[\mathrm{O}_{2}\right]_{\text {med }}\right)$ and can be predicted using the following equation:

$$
\left[\mathrm{O}_{2}\right]_{\mathrm{pkg}}=\frac{-\mathrm{C}+\sqrt{\mathrm{C}^{2}+4 \cdot \mathrm{K}_{1 / 2} \cdot\left[\mathrm{O}_{2}\right]_{\mathrm{atm}}}}{2}
$$

where

$$
\begin{aligned}
& \mathrm{C}=\mathrm{K}_{1 / 2}-\left[\mathrm{O}_{2}\right]_{\mathrm{atm}}+ \\
& \left(\frac{\mathrm{X}}{\mathrm{Y}}\right) \frac{\left(\mathrm{K}_{1 / 2}+\left[\mathrm{O}_{2}\right]_{\mathrm{med}}\right)\left(\left[\mathrm{O}_{2}\right]_{\mathrm{atm}}-\left[\mathrm{O}_{2}\right]_{\mathrm{med}}\right)}{\left[\mathrm{O}_{2}\right]_{\mathrm{med}}} \\
& \mathrm{X}=\frac{\mathrm{R}_{\mathrm{O}_{2}}}{\overline{\mathrm{R}}_{\mathrm{O}_{2}}} \\
& \mathrm{Y}=\frac{\mathrm{P}_{\mathrm{O}_{2}}}{\overline{\mathrm{P}}_{\mathrm{O}_{2}}}
\end{aligned}
$$

For example, if $\mathrm{O}_{2}$ uptake of the product in an individual package is 1.2 times the mean $\mathrm{O}_{2}$ uptake $(\mathrm{X}=1.2)$ and film permeability to $\mathrm{O}_{2}$ is 0.9 times the mean permeability $(\mathrm{Y}=0.9)$, the steady-state $\mathrm{O}_{2}$ partial pressure $\left(\left[\mathrm{O}_{2}\right]_{\mathrm{pkg}}\right)$ in that package will be 0.4 $\mathrm{kPa}$ (note that $1 \mathrm{kPa} \approx 1 \%$ at STP) if the packages were designed for an $\mathrm{O}_{2}$ partial pressure $\left(\left[\mathrm{O}_{2}\right]_{\mathrm{med}}\right)$ of $1 \mathrm{kPa}$ at steady state. For this example, a $\mathrm{K}_{1 / 2}$ value of $0.26 \mathrm{kPa}$ and an $\left[\mathrm{O}_{2}\right]_{\mathrm{atm}}$ of $21 \mathrm{kPa}$ were assumed.

With the knowledge of the frequency distributions of $\mathrm{O}_{2}$ uptake and film permeability to $\mathrm{O}_{2}$ and with the use of Eq. [1], the probability of $\left[\mathrm{O}_{2}\right]_{\mathrm{pkg}}$ being less than or equal to any given $\mathrm{O}_{2}$ partial pressure can be calculated (Talasila and Cameron, 1994).

With the assumption that there is no variation in film permeability to $\mathrm{O}_{2}$ (i.e., $\mathrm{Y}=1$ ), the following equation was developed to predict $\left[\mathrm{O}_{2}\right]_{\mathrm{med}}$ from Eq. [1] for a given minimum $\mathrm{O}_{2}$ limit for safe storage $\left(\left[\mathrm{O}_{2}\right]_{\min }\right)$, an associated probability of $\left[\mathrm{O}_{2}\right]_{\mathrm{pkg}}$ being equal to or less than $\left[\mathrm{O}_{2}\right]_{\min }$, and the known coefficient of variation of the product's $\mathrm{O}_{2}$ uptake $\left(\mathrm{CV}_{\mathrm{R}}\right.$, defined as the SD $\left(\sigma_{\mathrm{R}}\right)$ over the mean $\left(\overline{\mathrm{R}}_{\mathrm{O}_{2}}\right)$ of the population times $\left.100 \%\right)$ :

$$
\left[\mathrm{O}_{2}\right]_{\mathrm{med}}=\frac{-\mathrm{B}+\sqrt{\mathrm{B}^{2}+4 \cdot \mathrm{K}_{1 / 2} \cdot\left[\mathrm{O}_{2}\right]_{\mathrm{atm}}}}{2}
$$

where

$$
\begin{gathered}
\mathrm{B}=\mathrm{K}_{1 / 2}-\left[\mathrm{O}_{2}\right]_{\mathrm{atm}}+\frac{\left(\mathrm{K}_{1 / 2}+\left[\mathrm{O}_{2}\right]_{\text {min }}\right)\left(\left[\mathrm{O}_{2}\right]_{\mathrm{atm}}-\left[\mathrm{O}_{2}\right]_{\text {min }}\right)}{\left(1+\mathrm{z} \frac{\mathrm{CV}_{\mathrm{R}}}{100}\right)\left[\mathrm{O}_{2}\right]_{\text {min }}} \\
\mathrm{z}=\frac{\left(\mathrm{R}_{\mathrm{O}_{2}}-\overline{\mathrm{R}}_{\mathrm{O}_{2}}\right)}{\sigma_{\mathrm{R}}}
\end{gathered}
$$

z (standard normal deviate) values corresponding to a given probability can be obtained from numerical integration of the normal distribution density function (Table 1).

\section{Materials and Methods}

Plant material. Fresh broccoli was obtained from a commercial market in East Lansing, Mich. The broccoli had been harvested $\approx 5$ to 6 days earlier in the Salinas Valley, Calif. After discarding any decayed portion, broccoli florets of $\approx 5$ to $20 \mathrm{~g}$ were cut from the stalk and immediately used in the experiments.

Package construction. For all the packaging experiments, 26.8$\mu \mathrm{m}$-thick low-density polyethylene (LDPE) film (DOW Chemical, Midland, Mich.) was used. A septum made of silicone rubber on electrical insulation tape was attached to each package for extracting gas samples from the packages (Boylan-Pett, 1986).

Film permeability. Film permeabilities to $\mathrm{O}_{2}$ and $\mathrm{CO}_{2}$ were measured at $0,5,10,15$, and $20 \mathrm{C}$ using the system described by Beaudry et al. (1992), and Arrhenius equations for permeabilities as a function of temperature were developed (Table 2).

Table 1. z (standard normal deviate) values corresponding to different probabilities $(\%)$ calculated from numerical integration of the probability density function for normal distribution (Steel and Torrie, 1960).

\begin{tabular}{lc}
\hline \hline $\begin{array}{l}\text { Probability } \\
(\%)\end{array}$ & $\mathrm{z}$ \\
Value \\
\hline 50 & 0.00 \\
2 & 2.05 \\
1 & 2.33 \\
0.2 & 2.88 \\
0.1 & 3.09 \\
0.02 & 354 \\
0.01 & 3.72 \\
0.002 & 4.11 \\
0.001 & 4.27 \\
0.0002 & 4.62 \\
0.0001 & 4.77 \\
\hline
\end{tabular}


Gas analysis. Headspace $\mathrm{O}_{2}$ and $\mathrm{CO}_{2}$ concentrations were analyzed by withdrawing $0.5-\mathrm{ml}$ samples from the packages and injecting them into a $\mathrm{N}_{2}$ stream $\left(150 \mathrm{ml} \cdot \mathrm{min}^{-1}\right.$ flow rate), which was connected to an $\mathrm{O}_{2}$ analyzer ( $\mathrm{S}-3 \mathrm{~A} / \mathrm{II}$ with a calcia-zirconia electrochemical detection cell; Ametek Co., Thermox Instrument Div., Pittsburgh) and an infrared $\mathrm{CO}_{2}$ analyzer (ADC 225-Mk3; Analytical Development Co., Hertfordshire, England) in series. Headspace ethanol concentrations were analyzed by injecting separate $0.2-\mathrm{ml}$ gas samples from the packages into a gas chromatograph (Carle series 100; Hach Co., Loveland, Colo.) equipped with a porous polymer column (Haysep 80/100; Alltech Assoc., Deerfield, Ill.) and a flame ionization detector. For each reading in the gas analysis, an average of two samples was used. The concentrations were converted to partial pressures by multiplying with assumed total pressure $(101.325 \mathrm{kPa})$.

Frequency distribution of $\mathrm{O}_{2}$ partial pressures in cut-broccoli packages. Frequency distributions of steady-state package $\mathrm{O}_{2}$ at two $\mathrm{O}_{2}$ partial pressures were characterized at $0 \mathrm{C}$ by packaging 40 $\pm 0.5 \mathrm{~g}$ or $25 \pm 0.5 \mathrm{~g}$ of cut broccoli, respectively, in $10020 \times 15$ $\mathrm{cm}\left(600-\mathrm{cm}^{2}\right.$ film surface area) packages. In each package, an insert made of spunbonded polyethylene (Tyvek type 1059B; Du Pont, Wilmington, Del.) containing $10 \mathrm{~g} \mathrm{CaO}$ was used as $\mathrm{a}_{2}$ scrubber. This guaranteed that the variation in $\mathrm{O}_{2}$ partial pressures was not affected by the $\mathrm{CO}_{2}$ partial pressures in the packages. Oxygen partial pressures were periodically monitored from five additional packages to determine when they had reached steady-state levels. Oxygen partial pressures in packages reached steady state by 16 and 21 days of packaging with $40 \pm 0.5$ and $25 \pm 0.5 \mathrm{~g}$ of cut broccoli, respectively. Frequency distribution tables were developed and probabilities were calculated from the steady-state $\mathrm{O}_{2}$ partial pressure data (Steel and Torrie, 1960). The normality of the data was tested using PROC UNIVARIATE(SAS Institute, 1985a).

Measurement of $\mathrm{O}_{2}$ uptake, $\mathrm{RQ}$, and headspace ethanol. Cutbroccoli samples weighing from 10 to $160 \mathrm{~g}$ were packaged in separate $20 \times 15-\mathrm{cm}\left(600-\mathrm{cm}^{2}\right.$ surface area) packages and held at 0C to create a range of steady-state $\mathrm{O}_{2}$ partial pressures in the packages (Beaudry et al., 1992). Five replications were used for each weight. This number was found to be sufficient based on the expected variation in the product's respiration rate. Using the permeability values, area and thickness of the packaging film, weight of the product in the package, and the steady-state $\mathrm{O}_{2}$ and $\mathrm{CO}_{2}$ partial pressures in the package, $\mathrm{O}_{2}$ uptake and $\mathrm{CO}_{2}$ production were calculated based on the Fick's law of gas diffusion (Beaudry et al., 1992). RQ values at different $\mathrm{O}_{2}$ partial pressures were calculated from the corresponding $\mathrm{CO}_{2}$ production rate and the $\mathrm{O}_{2}$ uptake rate. A Michaelis-Menten-type equation was used to describe $\mathrm{O}_{2}$ uptake as a function of package $\mathrm{O}_{2}$ partial pressures. PROC NLIN was used for nonlinear regression analysis in devel-

Table 2. Permeabilities of the 26.81- $\mu$ m-thick LDPE film to $\mathrm{O}_{2}\left(\mathrm{P}_{\mathrm{O}_{2}}\right)$ and $\mathrm{CO}_{2}\left(\mathrm{P}_{\mathrm{CO}_{2}}\right)$ given as activation energies $\left(\mathrm{E}_{\mathrm{a}}\right)$ and Arrhenius constants $\left(\mathrm{A}_{\mathrm{r}}\right)$ and the corresponding coefficients of determination $\left(r^{2}\right) . \mathrm{E}_{\mathrm{a}}$ and $\mathrm{A}_{\mathrm{r}}$ values were obtained by fitting the measured permeability data at 0,5 , 10,15 , and $20 \mathrm{C}$ (three replications at each temperature) to the transformed Arrhenius equation: $\ln \left(\mathrm{P}_{\mathrm{i}}\right)=\ln \left(\mathrm{A}_{\mathrm{r}}\right)-\mathrm{E}_{\mathrm{a}} / \mathrm{RT}$, where $\mathrm{P}_{\mathrm{i}}$ is the permeability to $\mathrm{O}_{2}$ or $\mathrm{CO}_{2}\left(\mathrm{nmol} \cdot \mathrm{cm}^{-1} \cdot \mathrm{cm}^{-2}\right.$ per sec per $\left.\mathrm{kPa}\right)$; $\mathrm{E}_{\mathrm{a}}$ is the activation energy of $\mathrm{O}_{2}$ or $\mathrm{CO}_{2}$ permeation $\left(\mathrm{kJ} \cdot \mathrm{mol}^{-1}\right)$; $\mathrm{R}$ is the gas constant $\left(0.0083144 \mathrm{~kJ} \cdot \mathrm{mol}^{-1} \cdot \mathrm{K}^{-1}\right)$; and $\mathrm{T}$ is the temperature in $\mathrm{K}$.

\begin{tabular}{lccc}
\hline \hline & $\begin{array}{c}\mathrm{E}_{\mathrm{a}} \\
\left(\mathrm{kJ} \cdot \mathrm{mol}^{-1}\right)\end{array}$ & $\mathrm{A}_{\mathrm{r}}$ & $r^{2}$ \\
\hline $\mathrm{P}_{\mathrm{O}_{2}}$ & 35.64 & 7.86 & 0.982 \\
$\mathrm{P}_{\mathrm{CO}_{2}}$ & 32.00 & 9.81 & 0.982 \\
\hline
\end{tabular}

oping the model (SAS Institute, 1985b).

Frequency distribution of $\mathrm{CO}_{2}$ production rate. Cut-broccoli $\mathrm{CO}_{2}$ production rates at two $\mathrm{O}$ levels $(1.3 \mathrm{kPa}$ and $21.0 \mathrm{kPa})$ were measured using 80 samples at $0 \mathrm{C}$ with a flow-through system. The $\mathrm{CO}_{2}$ concentrations in the inlet and outlet of each 946-ml glass jar containing $100 \mathrm{~g}$ of cut broccoli were measured and, with the knowledge of the flow rate of the gas mixture $\left(25 \mathrm{ml} \cdot \mathrm{min}^{-1}\right), \mathrm{CO}_{2}$ production rate was calculated. Frequency distribution tables and the theoretical normal distributions based on the SD and the mean were developed (Steel and Torrie, 1960). The normality of the $\mathrm{CO}_{2}$ production rate data was tested using PROC UNIVARIATE.

\section{Results and Discussion}

Frequency distribution of $\mathrm{O}_{2}$ partial pressures in cut-broccoli packages. In one set of packages ( $40 \pm 0.5 \mathrm{~g}$ product weight), package $\mathrm{O}_{2}$ partial pressures varied from 1.2 to $3.6 \mathrm{kPa}$ and $\left[\mathrm{O}_{2}\right]_{\text {med }}$ was estimated as $2.2 \mathrm{kPa}$ (Fig. 1A). The range of package $\mathrm{O}_{2}$ partial pressures was 5.0 to $9.2 \mathrm{kPa}$ with an $\left[\mathrm{O}_{2}\right]_{\text {med }}$ of $6.7 \mathrm{kPa}$ in another set of packages $(25 \pm 0.5 \mathrm{~g}$ product weight) (Fig. 1B). From PROC UNIVARIATE, the significance level to reject the null hypothesis of normality of the distribution A data was estimated as 0.22. Although this was not sufficient evidence to reject the null hypothesis, it suggests the presence of slight non-normality. There was no evidence of non-normality of the distribution B data (significance level 0.54). The skewness of distribution A as estimated by PROC UNIVARIATE was slightly higher $(0.41)$ when compared to distribution B (0.26).

The non-normality of the package $\mathrm{O}_{2}$ partial pressure distributions at lower $\left[\mathrm{O}_{2}\right]_{\text {med }}$ is due to the shape of the $\mathrm{O}_{2}$ uptake curves, which are flat at higher package $\mathrm{O}_{2}$ levels and curved below a critical level depending on the product. Since package-to-package variation in $\mathrm{O}_{2}$ partial pressures in the curved region is lower than in the flat region, the distributions will become increasingly non-normal with decreasing $\left[\mathrm{O}_{2}\right]_{\text {med }}$.

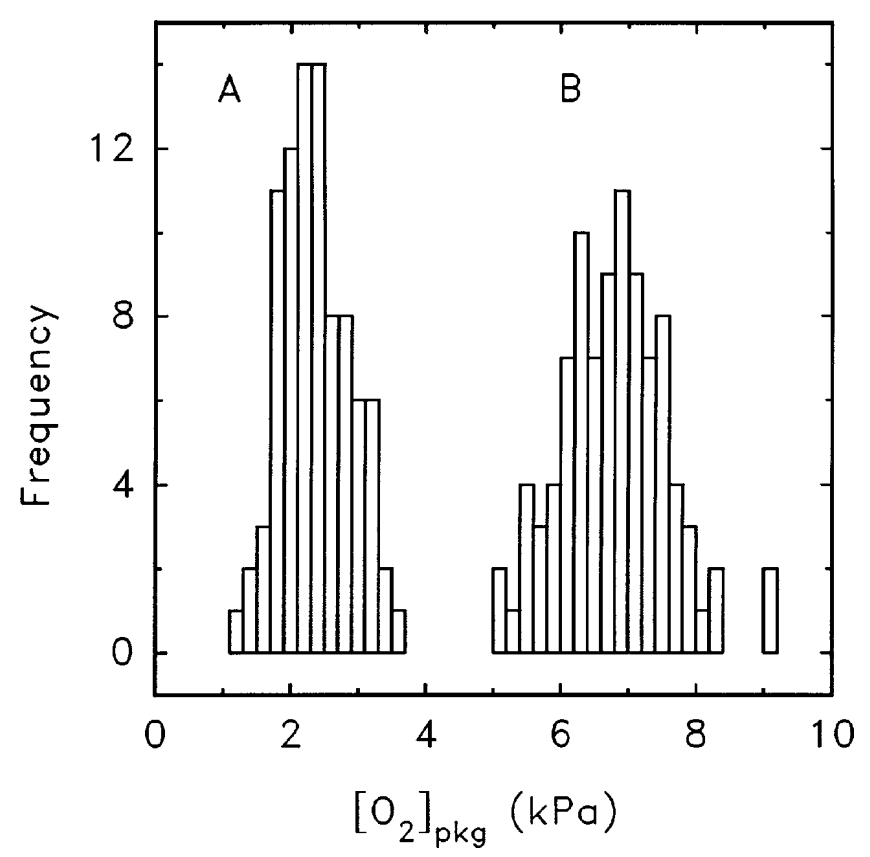

Fig. 1. Frequency distribution of $\mathrm{O}_{2}$ partial pressures in cut-broccoli packages at $0 \mathrm{C}$ $\left[\mathrm{O}_{2}\right]_{\text {med }}$ was $2.2 \mathrm{kPa}(\mathbf{A})$ for the set of the packages $(\mathrm{n}=88)$ with $40 \pm 0.5 \mathrm{~g}$ and was $6.7 \mathrm{kPa}(\mathbf{B})$ for the set $(\mathrm{n}=94)$ with $25 \pm 0.5 \mathrm{~g}$ of cut broccoli. Surface area of the LDPE film $(0.00268 \mathrm{~cm}$ thick $)$ used for both sets of packages was $600 \mathrm{~cm}^{2}$. 
Oxygen uptake, $R Q$, and headspace ethanol. The $\mathrm{O}_{2}$ uptake rate of cut broccoli was essentially constant above the package $\mathrm{O}_{2}$ partial pressure $\left(\left[\mathrm{O}_{2}\right]_{\mathrm{pkg}}\right)$ of $2 \mathrm{kPa}$ (Fig. $\left.2 \mathrm{~A}\right)$. Below $1 \mathrm{kPa}$, the rate decreased rapidly with a decrease in the $\mathrm{O}_{2}$ partial pressure. $\mathrm{A} \mathrm{K}_{1 / 2}$ value of 0.26 $\pm 0.025 \mathrm{kPa}$ and an $\mathrm{R}_{\mathrm{O}_{2}}$ max of $147 \pm 3 \mathrm{nmol} \cdot \mathrm{kg}^{-1} \cdot \mathrm{s}^{-1}$ were given by the nonlinear regression analysis of the $\mathrm{O}_{2}$ uptake data. $\mathrm{K}_{1 / 2}$ and $\mathrm{R}_{\mathrm{O}_{2}}{ }^{\max }$ intuitively indicate the $\mathrm{O}_{2}$ partial pressure corresponding to the half-maximum $\mathrm{O}_{2}$ uptake and the maximum $\mathrm{O}_{2}$ uptake of the product when $\mathrm{O}_{2}$ partial pressure is nonlimiting, respectively, at $0 \mathrm{C}$.

$\mathrm{K}_{1 / 2}$ is purely a regression constant that depends on $\mathrm{K}_{\mathrm{m}}$ (a parameter in Michaelis-Menten-type equation of $\mathrm{O}_{2}$ uptake as a function of $\mathrm{O}_{2}$ partial pressure in the product), skin permeability to $\mathrm{O}_{2}, \mathrm{O}_{2}$ uptake rate, and surface area-to-volume ratio. The $\mathrm{K}_{1 / 2}$ value obtained for cut broccoli was lower than those for blueberries (Cameron et al., 1994) and raspberries (Joles et al., 1994). This is presumably due to higher skin permeability, higher surface areato-volume ratio of cut broccoli, or both.

Carbon dioxide production data were calculated at various $\mathrm{O}_{2}$ partial pressures (Fig. 2B) and were used to calculate RQ (Fig. 2C). $\mathrm{RQ}$ was constant when $\mathrm{O}_{2}$ partial pressure was $>0.15 \mathrm{kPa}$. RQ increased rapidly at $<0.15 \mathrm{kPa} \mathrm{O}_{2}$ (Fig. 2C). Headspace ethanol partial pressures also increased in these packages (Fig. 2D), confirming the onset of anaerobic respiration.

All cut broccoli stored at $0 \mathrm{C}$, except that in the packages with $\mathrm{O}_{2}$ partial pressures $<0.15 \mathrm{kPa}$, was still green and otherwise in visibly good condition up to 52 days. Severe to moderate off-flavors
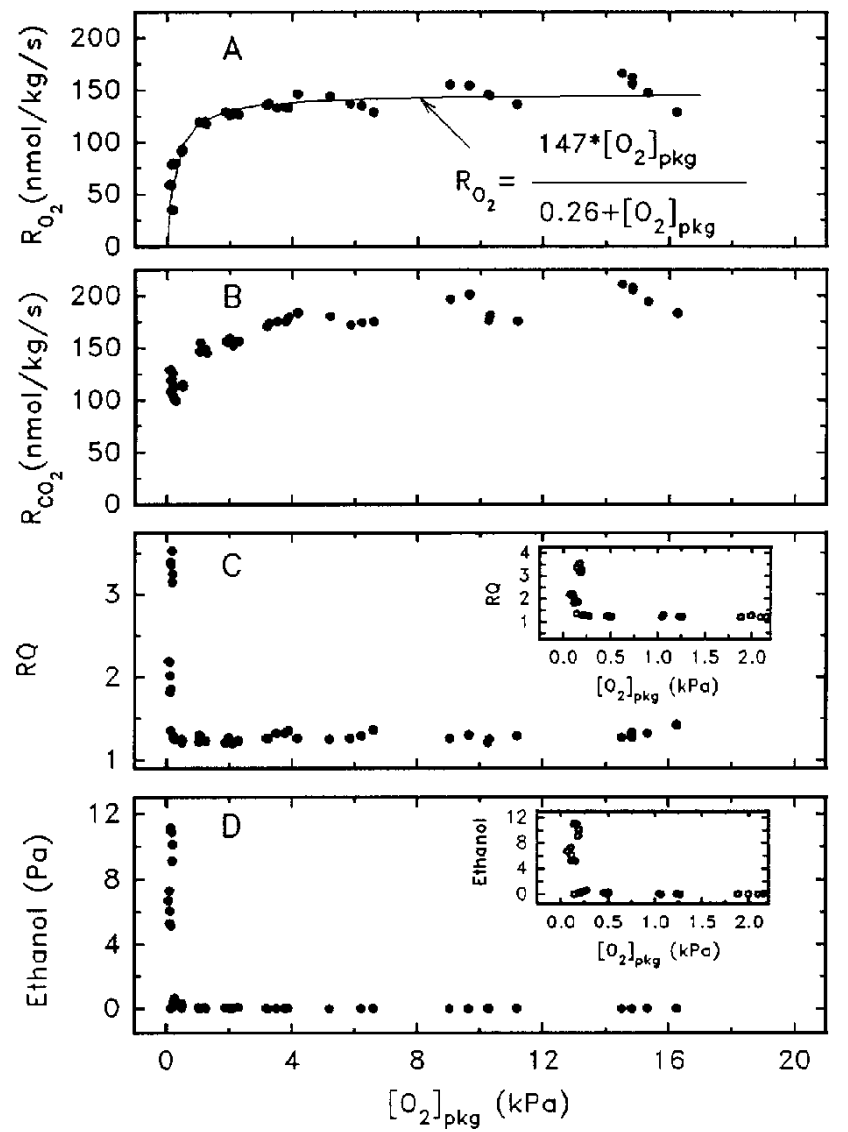

Fig. 2. The effect of package $\mathrm{O}_{2}$ partial pressures at $0 \mathrm{C}$ on $\mathrm{O}_{2}$ uptake rate $(\mathbf{A}), \mathrm{CO}_{2}$ production rate $(\mathbf{B}), \mathrm{RQ}(\mathbf{C})$, and ethanol partial pressures in the packages $(\mathbf{D})$. Cut broccoli ranging from 10 to $160 \mathrm{~g}$ was sealed in packages made of $0.00268-\mathrm{cm}$ thick LDPE film to generate different package $\mathrm{O}_{2}$ partial pressures. The surface area of the film used for all the packages was $600 \mathrm{~cm}^{2}$. The insets in Fig. $2 \mathrm{C}$ and $\mathrm{D}$ show the sharp increase in RQ and headspace ethanol partial pressures, respectively, at $<0.15 \mathrm{kPa} \mathrm{O}_{2}$. in packages with low $\mathrm{O}_{2}$ partial pressures $(<0.15 \mathrm{kPa})$ and slight off-flavors in the rest of the packages were noticed in informal taste panels. Slight to moderate wilting of the product was observed in those packages containing less mass of broccoli.

Frequency distribution of $\mathrm{CO}_{2}$ production rate. Carbon dioxide production rates closely approximated normal distribution at 1.3 $\mathrm{kPa}$ and $21 \mathrm{kPa}$ (Fig. 3). This was confirmed by statistical analysis. The significance levels for rejecting null hypothesis of the normality of the data at $1.3 \mathrm{kPa}$ and $21 \mathrm{kPa}$ were 0.77 and 0.71 , respectively.

The coefficient of variation of $\mathrm{CO}_{2}$ production rate was $\approx 5.8 \%$ at $1.3 \mathrm{kPa}$ and $\approx 4.2 \%$ at $21 \mathrm{kPa}$. For modeling purposes, an average coefficient of variation of $5 \%$ for the whole range of $\mathrm{O}_{2}$ partial pressures was taken. It was also assumed that variation in $\mathrm{O}_{2}$ uptake was equal to that of $\mathrm{CO}_{2}$ production.

Comparison of modeled and experimental frequency distributions. At $2.2 \mathrm{kPa}$, the probabilities predicted by the model using a $\mathrm{K}_{1 / 2}$ of $0.26 \mathrm{kPa}$ and $\mathrm{CV}_{\mathrm{R}}$ of $5 \%$ for $\mathrm{O}_{2}$ uptake closely agreed with the probabilities determined from the package $\mathrm{O}_{2}$ frequency distribution data (Fig. 4). In this example, it was assumed that there was no variation in film permeability $(\mathrm{Y}=1)$. The probabilities predicted by the model at an $\left[\mathrm{O}_{2}\right]_{\text {med }}$ of $6.7 \mathrm{kPa}$ were also close to the experimental probabilities. However, the agreement was not as close as when $\left[\mathrm{O}_{2}\right]_{\text {med }}$ was $2.2 \mathrm{kPa}$.

Some finite variation in film permeability is also expected, which would influence variation in package $\mathrm{O}_{2}$ partial pressures. At $6.7 \mathrm{kPa}$, when coefficients of variation of $5 \%$ for $\mathrm{O}_{2}$ uptake and $2.5 \%$ for film permeability were used, the cumulative probabilities predicted by the model agreed more closely with the experimental probabilities (data not shown). However, this is not sufficient evidence that there is indeed a $2.5 \%$ variation in film permeability.

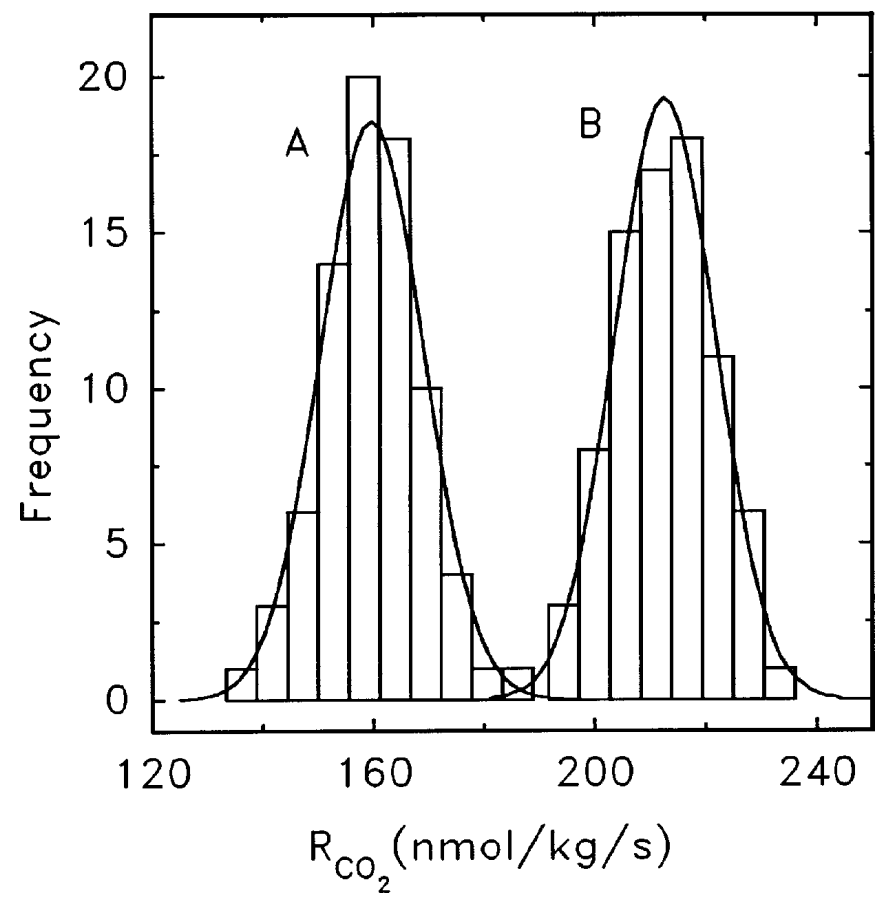

Fig. 3. Frequency distribution of $\mathrm{CO}_{2}$ production rates of cut broccoli at $\mathrm{O}_{2}$ partial pressures of $1.3 \mathrm{kPa}$ in 78 jars $(\mathbf{A})$ and $21.0 \mathrm{kPa}$ in 79 jars (B) at 0C. A flow-through system with $100 \mathrm{~g}$ of cut broccoli in each jar was used to measure $\mathrm{CO}_{2}$ production rates. Vertical bars indicate measured frequencies and curves show calculated theoretical normal distributions constructed based on the mean $\mathrm{CO}_{2}$ production rate $\left(160\right.$ and $213 \mathrm{nmol} \cdot \mathrm{kg}^{-1} \cdot \mathrm{s}^{-1}$ at $1.3 \mathrm{kPa}$ and $21.0 \mathrm{kPa}$, respectively) and SDS $\left(9.2\right.$ and $8.9 \mathrm{nmol} \cdot \mathrm{kg}^{-1} \cdot \mathrm{s}^{-1}$ at $1.3 \mathrm{kPa}$ and $21.0 \mathrm{kPa}$, respectively) of the measured data. 
The higher variation in package $\mathrm{O}_{2}$ partial pressures than predicted could be due to the combined variation in film permeability and other package variables such as surface area, thickness, or the product's mass.

The close agreement between the modeled probabilities, assuming no variation in film permeability, and the experimentally observed data at $2.2 \mathrm{kPa}$ and $6.7 \mathrm{kPa}$, suggests that the package-to-package variation in film permeability was relatively low for the LDPE film used in the experiments. For more specialized films that are less uniform in composition, the variation would most likely be higher. Although it is possible to determine the coefficient of variation of film permeability experimentally, the time and effort required to measure the permeability accurately for hundreds of film samples make it tedious. However, to use MAs commercially, it will be necessary for the packer to have an accurate knowledge of the permeability of the film being used and its variability.

At $6.7 \mathrm{kPa}$, when coefficients of variation of $6 \%$ (instead of $5 \%$ ) for $\mathrm{O}_{2}$ uptake and $0 \%$ for film permeability were used, the predictions were also closer to the experimental data (data not shown). Because the amount of cut broccoli in the packages at $6.7 \mathrm{kPa}$ was relatively small, a higher coefficient of variation for $\mathrm{O}_{2}$ uptake would be expected. Theoretically, the SD of the means is inversely proportional to the square root of the sample size (Steel and Torrie, 1960). However, since $100 \mathrm{~g}$ of cut broccoli was placed in each jar for measuring the variation in $\mathrm{CO}_{2}$ production rate, applying the theoretical relationship between the coefficient of variation and the sample size yielded $\mathrm{CV}_{\mathrm{R}} \mathrm{s}$ of $7.9 \%$ and $10 \%$ at $2.2 \mathrm{kPa}(40-\mathrm{g}$ sample size) and $6.7 \mathrm{kPa}(25-\mathrm{g}$ sample size $)$, respectively. When these $\mathrm{CV}_{\mathrm{R}} \mathrm{s}$ were used, the modeled probabilities overestimated the range of package $\mathrm{O}_{2}$ partial pressures. In the case of cut broccoli, applying the theoretical relationship between the coefficient of variation and the sample size is rather superficial, since a cutbroccoli sample is not homogeneous and is a combination of stems

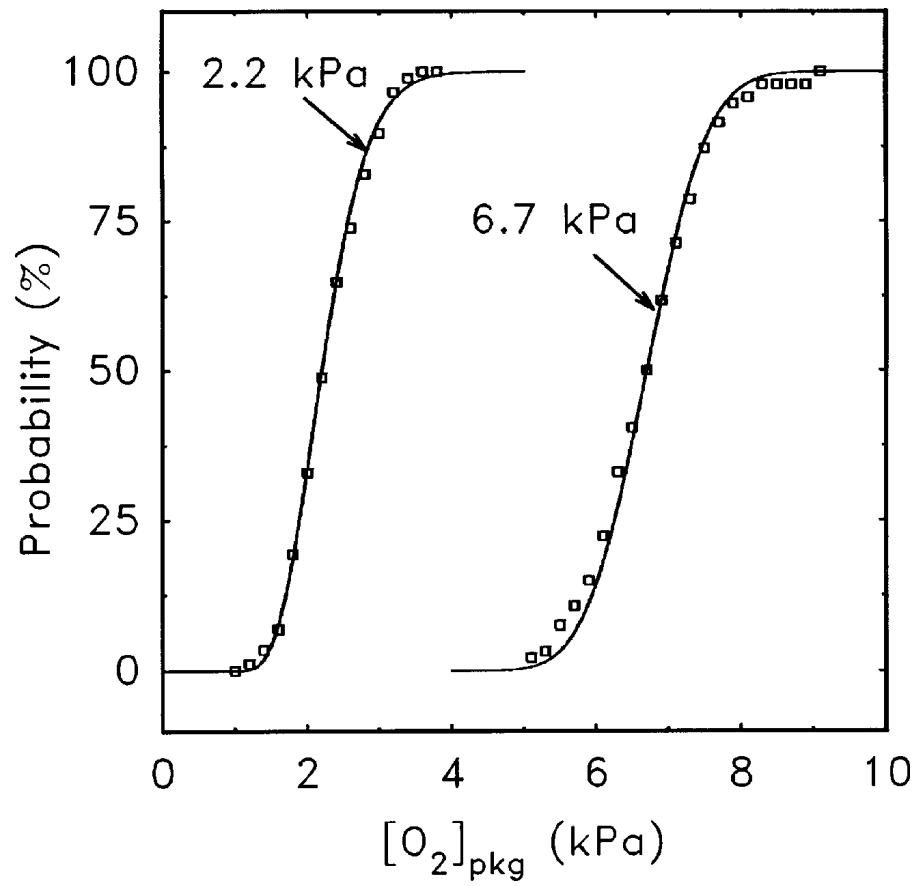

Fig. 4. Comparison of the probabilities of package $\mathrm{O}_{2}$ partial pressures being equal to or less than a certain $\mathrm{O}_{2}$ partial pressure calculated from the package experiments (口) (Fig. 1) with those predicted by the model $(\nabla)$ at $2.2 \mathrm{kPa}$ and $6.7 \mathrm{kPa}$. The model predictions were based on $\mathrm{CV}_{\mathrm{R}}$ of $5 \%$ and $\mathrm{K}_{1 / 2}$ of $0.26 \mathrm{kPa}$ for $\mathrm{O}_{2}$ uptake and $0 \%$ coefficient variation in film permeability. and florets and may consist of parts from one or more different stalks. The theoretical relationship may be more appropriate for studying the variation among the whole stalks or in general among whole fruit and vegetables.

It was noted that the range of package $\mathrm{O}_{2}$ partial pressures was small at $2.2 \mathrm{kPa}$ (Fig. 1). This is presumably due to the rapid decrease in $\mathrm{O}_{2}$ uptake at $<1 \mathrm{kPa}$ (Fig. 2A). A decrease in the range of $\left[\mathrm{O}_{2}\right]_{\mathrm{pkg}}$ with a decrease in $\left[\mathrm{O}_{2}\right]_{\mathrm{med}}$ can also be observed from the predicted probabilities generated using the model (Fig. 5).

Target median $\mathrm{O}_{2}$ partial pressures for designing $M A$ packages. Eq. [2] was used to predict the required target $\left[\mathrm{O}_{2}\right]_{\text {med }}$ for a given probability of $\left[\mathrm{O}_{2}\right]_{\mathrm{pkg}}$ being equal to or less than a minimum $\mathrm{O}_{2}$ partial pressure $\left(\mathrm{Table} 3 ;\left[\mathrm{O}_{2}\right]_{\text {min }}\right.$ ). If cut-broccoli packages were designed for an $\left[\mathrm{O}_{2}\right]_{\mathrm{med}}$ of $0.21 \mathrm{kPa}$, the probability of $\left[\mathrm{O}_{2}\right]_{\mathrm{pkg}}$ being equal to or less than the anaerobic $\mathrm{O}_{2}$ partial pressure limit as observed in the current study at $0 \mathrm{C}(0.15 \mathrm{kPa} \mathrm{O})$ would be $0.0001 \%$ (Table 3 ). The predicted $\left[\mathrm{O}_{2}\right]_{\text {med }}$ is only valid if packaged broccoli has respiration characteristics equal to those obtained in the current study.

It is possible that the $\mathrm{O}_{2}$ partial pressures in some of the packages designed for low probabilities of $\left[\mathrm{O}_{2}\right]_{\mathrm{pkg}}$ being equal to or less than a particular $\left[\mathrm{O}_{2}\right]_{\min }$ may be higher than the optimum storage levels. For example, there is a $20 \%$ probability that the packages designed for an $\left[\mathrm{O}_{2}\right]_{\text {med }}$ of $2.5 \mathrm{kPa}$ will have $\mathrm{O}_{2}$ partial pressures $>3 \mathrm{kPa}$ (Fig. 5). The median $\mathrm{O}_{2}$ partial pressure may be decreased to reduce the probability of $\left[\mathrm{O}_{2}\right]_{\mathrm{pkg}}$ being greater than optimum levels. However, this increases the probability of generating $\mathrm{O}_{2}$ partial pressures lower than $\left[\mathrm{O}_{2}\right]_{\min }$ (Table 3). A compromise has to be made between the probability of exposing the broccoli in some packages to $\mathrm{O}_{2}$ partial pressures below $\left[\mathrm{O}_{2}\right]_{\min }$ and in other packages to $\mathrm{O}_{2}$ partial pressures above optimum levels.

The following steady-state equation was used for designing MA packages for cut broccoli at $0 \mathrm{C}$ based on the median $\mathrm{O}_{2}$ partial pressures predicted by Eq. [2]:

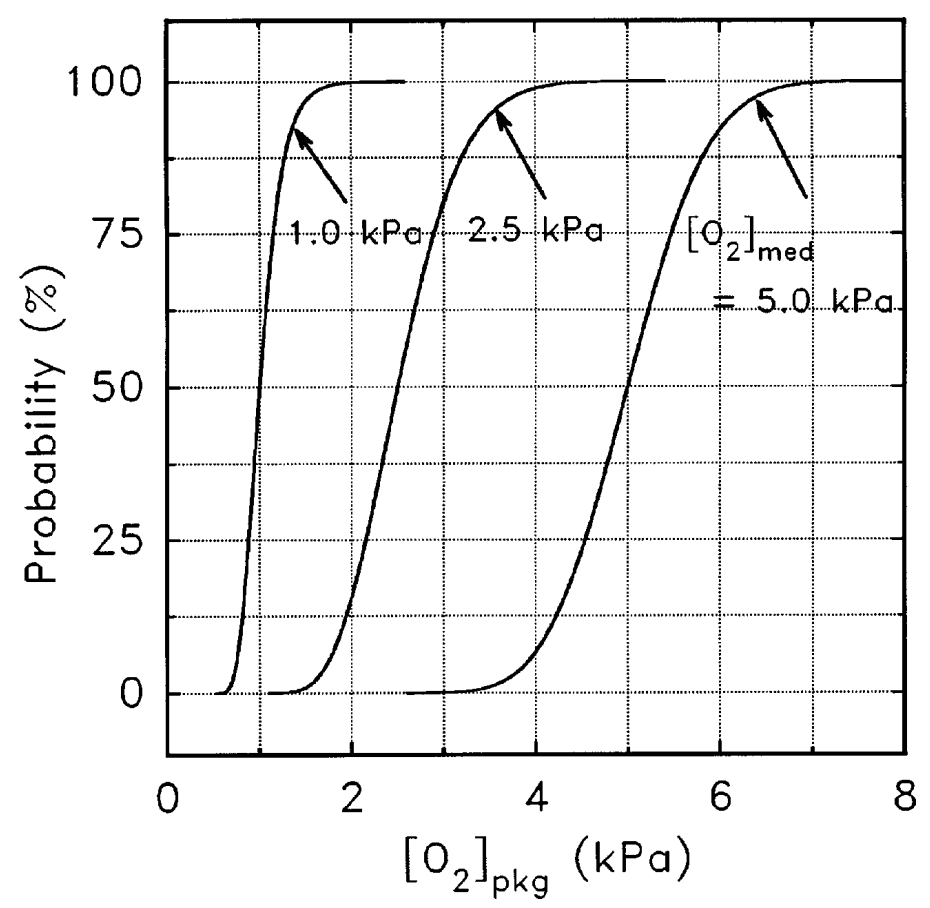

Fig. 5. Probabilities of package $\mathrm{O}_{2}$ partial pressures being equal to or less than a certain $\mathrm{O}_{2}$ partial pressure in cut-broccoli packages at different $\left[\mathrm{O}_{2}\right]_{\text {med }}$ predicted by the model. The predictions were based on a $\mathrm{CV}_{\mathrm{R}}$ of $5 \%$ and a $\mathrm{K}_{1 / 2}$ of $0.26 \mathrm{kPa}$ for $\mathrm{O}_{2}$ uptake and $0 \%$ coefficient variation in film permeability. 


$$
\frac{\overline{\mathrm{P}}_{\mathrm{O}_{2}} \cdot \mathrm{A}}{\Delta \mathrm{x}}\left(\left[\mathrm{O}_{2}\right]_{\mathrm{atm}}-\left[\mathrm{O}_{2}\right]_{\mathrm{med}}\right)=\overline{\mathrm{R}}_{\mathrm{O}_{2}} \cdot \mathrm{W}
$$

The results are given in Table 4 . The term $\left(\overline{\mathrm{P}}_{\mathrm{O}_{2}} \times \mathrm{A} \times \Delta \mathrm{x}^{-1} \cdot \mathrm{W}^{-1}\right)$ gives the permeability of the appropriate packaging film, given the area of the film (A), the weight of the product in the package (W), and the thickness of the film $(\Delta \mathrm{x})$. At any $\left[\mathrm{O}_{2}\right]_{\min }$, a small change in any of the variables in the term $\left(\overline{\mathrm{P}}_{\mathrm{O}_{2}} \times \mathrm{A} \times \Delta \mathrm{x}^{-1} \cdot \mathrm{W}^{-1}\right)$ tremendously changes the probability of $\left[\mathrm{O}_{2}\right]_{\mathrm{pkg}}$ being equal to or less than $\left[\mathrm{O}_{2}\right]_{\text {min }}$. For example, a $10 \%$ decrease in film permeability is predicted to increase the probability from $0.0001 \%$ to $1 \%$ (Table 4). Therefore, using films that have considerable variation in permeabilities for MA packaging requires designing packages for very low probability levels (in the order of $0.0001 \%$ ). Also, considerable care should be taken to avoid the package-to-package variation in film surface area and product weight.

In this study, product-to-product variation in respiration rate within a small sample of a single consignment of broccoli was investigated. There are other factors such as harvesting season, variety, or growing conditions that may cause additional variation in respiration rate. The effects of this variation on package $\mathrm{O}_{2}$ may be reduced by measuring the respiration rate of a specific crop before packaging and adjusting the packaging variables such as the area of the film and product weight accordingly. When designing large packages, the possibility of partial-pressure gradients within the packages should also be considered (Emond and Chau, 1990).

The fact that the cut broccoli, except in the packages with $\mathrm{O}_{2}$ partial pressures $<0.15 \mathrm{kPa}$, was visibly in good condition at $0 \mathrm{C}$ for 52 days points out the importance of temperature control for broccoli storage. In addition to its direct effect on the product's deterioration rate, an increase in temperature may decrease the package $\mathrm{O}_{2}$ partial pressures below the minimum limit causing off-flavors and physiological damage (Cameron et al., 1994; Wang and Hruschka, 1977). As the absolute control of temperature during shipping and marketing is limited by current technology,

Table 3. Model predictions for target $\left[\mathrm{O}_{2}\right]_{\text {med }}$ required for different probabilities of the package $\mathrm{O}_{2}$ partial pressures being equal to or less than a given $\left[\mathrm{O}_{2}\right]_{\min }$ in cut-broccoli modified-atmosphere packages at $0 \mathrm{C}$. The predictions were based on a $\mathrm{CV}_{\mathrm{R}}$ of $5 \%$ and $\mathrm{K}_{1 / 2}$ of $0.26 \mathrm{kPa}$ for $\mathrm{O}_{2}$ uptake and $0 \%$ variation in film permeability.

\begin{tabular}{lcccc}
\hline \hline Probability & \multicolumn{5}{c}{$\left[\mathrm{O}_{2}\right]_{\text {min }}$} \\
\cline { 2 - 5 }$(\%)$ & $1.00 \mathrm{kPa}$ & $0.50 \mathrm{kPa}$ & $0.25 \mathrm{kPa}$ & $0.15 \mathrm{kPa}$ \\
\hline \multirow{5}{*}{$k P a$} & 0.69 & 0.31 & 0.18 \\
1 & 1.59 & 0.78 & 0.34 & 0.19 \\
0.1 & 1.86 & 0.55 & 0.36 & 0.20 \\
0.01 & 2.10 & 1.01 & 0.39 & 0.21 \\
0.0001 & 2.54 & &
\end{tabular}

Table 4. Film specifications $\left(\overline{\mathrm{P}}_{\mathrm{O}_{2}} \times \mathrm{A} \times \Delta \mathrm{x}^{-1} \times \mathrm{W}^{-1}, \mathrm{nmol} \cdot \mathrm{kPa}^{-1} \cdot \mathrm{s}^{-1} \mathrm{per} \mathrm{kg}\right)$ for cut broccoli modified-atmosphere packaging at $0 \mathrm{C}$ for different probabilities of $\left[\mathrm{O}_{2}\right]_{\mathrm{pkg}}$ being equal to or less than $\left[\mathrm{O}_{2}\right]_{\mathrm{min}}$.

\begin{tabular}{|c|c|c|c|c|}
\hline \multirow{2}{*}{$\begin{array}{l}\text { Probability } \\
(\%)\end{array}$} & \multicolumn{4}{|c|}{$\left[\mathrm{O}_{2}\right]_{\min }$} \\
\hline & $1.00 \mathrm{kPa}$ & $0.50 \mathrm{kPa}$ & $0.25 \mathrm{kPa}$ & $0.15 \mathrm{kPa}$ \\
\hline \multicolumn{5}{|c|}{$\mathrm{nmol} \cdot \mathrm{kPa}^{-1} \cdot \mathrm{s}^{-1}$ per $\mathrm{kg}$} \\
\hline 1 & 6.52 & 5.28 & 3.88 & 2.88 \\
\hline 0.1 & 6.74 & 5.45 & 4.02 & 2.98 \\
\hline 0.01 & 6.93 & 5.60 & 4. 12 & 3.06 \\
\hline 0.0001 & 7.24 & 5.85 & 4.31 & 3.20 \\
\hline
\end{tabular}

temperature variation and inherent variation in respiration rate and film permeability should be considered when designing MA packages. The appropriate package specifications may be predicted by incorporating the variation model into the approach suggested by Cameron et al. (1994) for temperature variation problems.

For some products, off-flavors may take a few days to develop after the product is exposed to anaerobic $\mathrm{O}_{2}$ partial pressure, especially at low temperatures (Ke et al., 1991a, 1991b). Also, off-flavors, which are produced due to the product's exposure to injurious $\mathrm{O}_{2}$ and $\mathrm{CO}_{2}$ levels, may be reduced in some cases by subsequently exposing the product to air (Kasmire et al., 1974). In these situations, variation in package gas partial pressures can be tolerated to a certain extent. When designing MA packages, the probability level of package $\mathrm{O}_{2}$ being less than or equal to a given minimum level should be selected based on the severity of the effect of injurious gas levels on product quality and subsequent loss in marketability.

\section{Appendix}

A = Film surface area of the package $\left(\mathrm{cm}^{2}\right)$.

$\mathrm{CV}_{\mathrm{R}}=$ Coefficient of variation of the frequency distribution of $\mathrm{R}_{\mathrm{O}_{2}}(\%)$. $\mathrm{K}_{\mathrm{m}}=\mathrm{A}$ parameter in Michaelis-Menten-type equation of $\mathrm{O}_{2}$ uptake as a function of $\mathrm{O}_{2}$ partial pressure in the product $(\mathrm{kPa})$.

$\mathrm{K}_{1 / 2}=$ A parameter in Michaelis-Menten-type equation of $\mathrm{O}_{2}$ uptake as a function of package $\mathrm{O}_{2}$ partial pressure $(\mathrm{kPa})$.

$\left[\mathrm{O}_{2}\right]_{\mathrm{atm}}=\mathrm{O}_{2}$ partial pressure outside the package $(\mathrm{kPa})$.

$\left[\mathrm{O}_{2}\right]_{\text {med }}=$ Median steady-state package $\mathrm{O}_{2}$ partial pressure $(\mathrm{kPa})$.

$\left[\mathrm{O}_{2}\right]_{\mathrm{pkg}}=$ Steady-state $\mathrm{O}_{2}$ partial pressure in a package $(\mathrm{kPa})$.

$\mathrm{P}_{\mathrm{O}_{2}}=$ Permeability to $\mathrm{O}_{2}$ of a packaging film $\left(\mathrm{nmol} \mathrm{cm}-1 \cdot \mathrm{cm}^{-2}\right.$ per sec per $\mathrm{kPa})$.

$\overline{\mathrm{P}}_{\mathrm{O}_{2}}=$ Mean film permeability to $\mathrm{O}_{2}\left(\mathrm{nmol} \cdot \mathrm{cm}^{-1} \cdot \mathrm{cm}^{-2}\right.$ per sec per $\left.\mathrm{kPa}\right)$.

$\mathrm{R}_{\mathrm{O}_{2}}=\mathrm{O}_{2}$ uptake of the product in a package $\left(\mathrm{nmol} \cdot \mathrm{kg}^{-1} \cdot \mathrm{s}^{-1}\right)$.

$\overline{\mathrm{R}}_{\mathrm{O}_{2}}=$ Mean $\mathrm{O}_{2}$ uptake of the product $\left(\mathrm{nmol} \cdot \mathrm{kg}^{-1} \cdot \mathrm{s}^{-1}\right)$.

$\mathrm{R}_{\mathrm{O}_{2}}$ max $=$ A parameter in Michaelis-Menten-type equation of $\mathrm{O}_{2}$ uptake as a

function of package $\mathrm{O}_{2}$ partial pressure $\left(\mathrm{nmol} \cdot \mathrm{kg}^{-1} \cdot \mathrm{s}^{-1}\right)$.

$\mathrm{X}=$ Fraction $\mathrm{R}_{\mathrm{O}_{2}} / \overline{\mathrm{R}}_{\mathrm{O}_{2}}$.

$\mathrm{Y}=$ Fraction $\mathrm{P}_{\mathrm{O}_{2}} / \overline{\mathrm{P}}_{\mathrm{O}_{2}}$.

$\mathrm{W}=$ Weight of the product in a package $(\mathrm{kg})$.

$\mathrm{z}=$ Standard normal deviate.

$\Delta \mathrm{x}=$ Thickness of the packaging film (cm).

$\sigma_{\mathrm{R}}=\mathrm{SD}$ of $\mathrm{O}_{2}$ uptake population $\left(\mathrm{nmol} \cdot \mathrm{kg}^{-1} \cdot \mathrm{s}^{-1}\right)$.

\section{Literature Cited}

Beaudry, R.M., A.C. Cameron, A. Shirazi, and D.L. Dostal-Lange. 1992. Modified-atmosphere packaging of blueberry fruit: Effect of temperature on package $\mathrm{O}_{2}$ and $\mathrm{CO}_{2}$. J. Amer. Soc. Hort. Sci. 117:436-441.

Boylan-Pett, W. 1986. Design and function of a modified atmosphere package for tomato fruit. MS thesis. Michigan State Univ., East Lansing. Cameron, A.C., R.M. Beaudry, N.H. Banks, and M.V. Yelanich. 1994. Modified-atmosphere packaging of blueberry fruit: Modeling respiration and package oxygen partial pressure as a function of temperature. J. Amer. Soc. Hort. Sci. 119:534-539.

Cameron, A.C., W. Boylan-Pett, and J. Lee. 1989. Design of modified atmosphere packaging systems: Modeling oxygen concentrations within sealed packages of tomato fruits. J. Food Sci. 54:1413-1416, 1421.

Emond, J.P. and K.V. Chau. 1990. Effects of package physical properties on gas concentration profiles in MA packaging. Amer. Soc. Agr. Eng., St. Joseph, Mich. Paper no. 90-6511.

Joles, D.W., A.C. Cameron, A. Shirazi, P.D. Petracek, and R.M. Beaudry. 1994. Modified-atmosphere packaging of 'Heritage' red raspberry fruit: Respiratory response to reduced oxygen, enhanced $\mathrm{CO}_{2}$ and temperature. J. Amer. Soc. Hort. Sci. 119:540-454. 
Kader, A.A., D. Zagory, and E.L. Kerbel. 1989. Modified atmosphere packaging of fruits and vegetables. Critical Rev. Food Sci. Nutr. 28:1-30.

Kasmire, R.F., A.A. Kader, and J.A. Klaustermeyer. 1974. Influence of aeration rate and atmospheric composition during simulated transit on visual quality and off-odor production by broccoli. HortScience 9:228229.

Ke, D., L. Goldstein, M. O’Mahony, and A.A. Kader. 1991a. Effects of short-term exposure to low $\mathrm{O}_{2}$ and high $\mathrm{CO}_{2}$ atmospheres on quality attributes of strawberries. J. Food Sci. 56:50-54.

Ke, D., L. Rodriguez-Sinobas, and A.A. Kader. 1991b. Physiology and prediction of fruit tolerance to low-oxygen atmospheres. J. Amer. Soc. Hort. Sci. 116:253-260.

Lee, D.S., P.E. Haggar, J. Lee, and K.L. Yam. 1991. Model for fresh produce respiration in modified atmospheres based on principles of enzyme kinetics. J. Food Sci. 56:1580-1585.

Lipton, W.J. and C.M. Harris. 1974. Controlled atmosphere effects on the market quality of stored broccoli. J. Amer. Soc. Hort. Sci. 99:200-205.

Makhlouf, J., F. Castaigne, J. Arul, C. Willemot, and A. Gosselin. 1989.
Long-term storage of broccoli under controlled atmosphere. HortScience 24:637-639.

Refrigeration Research Foundation. 1988. Broccoli: Storage, handling and freezing. Commodity storage manual. The Refrigeration Res. Foundation, Bethesda, Md.

SAS Institute. 1985a. SAS user's guide: Basics. version 5. SAS Inst., Cary, N.C.

SAS Institute. 1985b. SAS user's guide: Statistics. version. SAS Inst., Cary, N.C.

Smith, W.H. 1940. The storage of broccoli and cauliflower. J. Pomol. Hort. Sci. 18:287-293.

Steel, R.G.D. and J.H. Torrie. 1960. Principles and procedures of statistics. McGraw-Hill, New York.

Talasila, P.C. and A.C. Cameron. 1994. Modeling distribution of steady-state $\mathrm{O}_{2}$ levels in modified atmosphere packages: An approach for designing safe packages. J. Food Proc. Eng. (In press.)

Wang, C.Y. and H.W. Hruschka. 1977. Quality maintenance in polyethylene-packaged broccoli. U.S. Dept. of Agr. Mktg. Res. Rpt. 1085. 